Tomasz Nakoneczny

Uniwersytet im. A. Mickiewicza w Poznaniu

\title{
Ponowoczesność, czyli człowieczeństwo zdegradowane?
}

\section{POSTMODERNITY OR DEGRADED HUMANITY?}

The article poses the question on conditio humana on the background of conflict between the two ideological orientation of our time: constructivism and essentialism. The first orientation continues the project of human emancipation, whose initial ideas shaped the Enlightenment. In this framework, the man is a constructor of his world. The second orientation includes a number of traditions and paradigms, describing the man as irrevocably immersed in the world of standards and truths derived from the non-human reality. The author reflects on the implications of the this ideological conflict to our ideas of man as a creature of special moral status.

Key words: postmodernity, humanity, essentialism, constructivism, conflict.

Jeśliby przyjąć, że istotnym wyznacznikiem tożsamości epok są charakterystyczne dla nich sprzeczności (między np. dążeniem do racjonalności i irracjonalnością, między barbarzyństwem i kulturą, ładem i buntem, opresją i wolnością - by wymienić te bodaj najczęściej przywoływane), o czasie zwanym ponowoczesnym (jedno z kilku konkurujących w dyskursie określeń, które możemy przyjąć bez ryzyka nadużycia) wolno powiedzieć, że wśród licznych trawiących go sprzeczności, ukrytych bądź jawnych, jest i ta, która bierze się z dwóch wyraźnie przeciwstawnych, a silnie świadomość reflektującą naznaczających wizji człowieczeństwa. 
Pierwsza z tych wizji zakłada, że wyróżniającą właściwością kondyNauka cji człowieka współczesnego jest - przynajmniej w obrębie cywilizacji zachodniej - jej płynność i przygodność, będące następstwem przezwyciężenia tradycyjnych (metafizycznych, religijnych, społecznych) sposobów uprawomocniania (na gruncie tej koncepcji należałoby mówić raczej o zniewalaniu) człowieka jako istoty o szczególnym, uprzywilejowanym moralnie statusie we Wszechświecie. Człowiek wyzbywszy się, powiadają zwolennicy tej orientacji, konieczności fundowania swojego moralnego habitus na podstawach innych aniżeli własna wola, intelekt czy wyobraźnia, staje się istotą prawdziwie suwerenną, zdolną wreszcie (to znaczy po raz pierwszy w historii) do organizowania swojego świata w sposób zarazem prawdziwie wolny, twórczy, jak pokojowy. Albowiem człowiek to istota z natury dobra i do rozumnych form współżycia ze światem skłonna; źródłem jej odwiecznej deprawacji pozostaje wadliwy mechanizm społeczny, który z kolei napędza złudna wiara, że jest w człowieku cokolwiek trwale esencjalnego, co wykracza poza jego historycznie zmienną naturę i co wymyka się społecznemu stanowieniu. Nietrudno dostrzec tu genetyczne powiązania z oświeceniowym konstruktywizmem głoszącym możliwość stworzenia lepszego człowieka, kreatora rzeczywistości ekscytującej swoją nowością i bogactwem potencji. Wizję tę cechuje młodzieńczy optymizm, który stosunkowo łatwo przychodzi dezawuować komuś, kto przywykł rzeczywistość oceniać ze stanowiska potocznego zdrowego rozsądku, lecz który niełatwo poddaje się krytyce na gruncie dyskursywnym ${ }^{1}$.

Druga wizja, jakkolwiek milcząco uznaje pewną ogólną zasadność diagnozy leżącej u podstaw pierwszej (postępujący rozpad tradycyjnych form myślenia o człowieku, wspólnocie etc.), zupełnie odmiennie interpretuje jej znaczenie. W obrazie człowieczeństwa wyzwolonego (tu należałoby raczej powiedzieć - rzekomo wyzwolonego) z tradycyjnych uzasadnień upatruje oznak jego faktycznej degradacji. W istocie bowiem, zauważają przedstawiciele tego stanowiska, nie sposób wyobrazić sobie projekt człowieka czy społeczeństwa, który by nie wywodził swoich racji z jakichś przesłanek metafizycznych. Kwestionowanie tego faktu jest czymś więcej niż intelektualnym błędem: wiedzie do ślepego na rzeczywisty stan rzeczy i zgubnego w skutkach relatywizmu. Nie dość jednak tego: nie tylko przegapienie istnienia

Trudność ta wynika, jak się wydaje, z faktu, że dyskurs jednej ze stron debaty odwołuje się w tym względzie do pojęć respektowanych - nie tylko na zasadzie pewnego rodzaju profesjonalnego obyczaju, ale również ze względów moralnych - przez drugą stronę, czego nie czyni, a w każdym razie czynić nie musi, zdrowy rozsądek. Zob. też przypis nr 32. 
takich przesłanek jest groźne, ale i hołdowanie - jakkolwiek na ogół nieuświadomione - przesłankom fałszywym. Głównym nieszczę- Nauka ściem naszego czasu jest - upraszczając nieco tę wizję - rezygnacja z prawdy jako naturalnego układu odniesienia dla ludzkich myśli i poczynań, a także - w niemniejszym stopniu - afirmacja pozornie niemetafizycznej polityki emancypacyjnej zmierzającej do uczynienia kultury przestrzenią nieustannie rozszerzanego zakresu wolności i kreacyjności, a tradycyjne ujęcia prawdy uznają za nieuzasadnione obciążenia na tej drodze. Faktyczna metafizyczność zasadza się tutaj na oświeceniowym dogmacie o naturalnej dobroci i rozumności człowieka, będącym - co niejednokrotnie zauważano - zredukowaną wersją chrześcijańskiej koncepcji osoby ludzkiej². Nietrudno przeto zrozumieć, że tę z kolei wizję przepaja niepokój, przybierający niekiedy rozmiary historiozoficznego katastrofizmu, niekiedy zaś skłaniający do postaw eskapistycznych; natomiast w swoich odmianach chrześcijańskich łagodzony jest ów niepokój przez wiarę w teleologiczny przebieg procesu dziejowego i jego paruzyjny sens.

Choć spotykają się te wizje w obrębie myśli postmodernistycznej (to również jedno z określeń, które przyjąć można dla zachowania terminologicznej spójności wywodu), ciążą one ku rozmaitym tradycjom (oświecenie versus nurty kontestujące je) i co ważniejsze - różne powodują konsekwencje ideologiczne, a nawet praktyczne. Niebawem wrócimy do tego wątku.

Teraz wypada postawić pytanie o istotność zarysowanej dychotomii. Jeśli bowiem wśród endemicznych sprzeczności epoki, wymienianych jako kluczowe przez rozmaitych a wpływowych dziś myślicieli, takich jak choćby Francis Fukuyama (konflikt popędów megalotymicznych i izotymicznych) ${ }^{3}$, Zygmunt Bauman (konflikt między potrzebą

2 Jedną $\mathrm{z}$ istotniejszych implikacji tego przekształcenia jest utożsamienie grzeszności z błędem, a zła z określoną konfiguracją społeczną (społeczeństwo nieegalitarne). Być może należałoby w tym (to znaczy w bazowaniu na kategoriach fundamentalnie moralnych) widzieć jeden z powodów, dla których oświeceniowy projekt emancypacji człowieka nacechowany został u zarania ukrytą nietolerancją.

3 Swoje stanowisko w tej sprawie rozwinął Fukuyama obszernie w Końcu historii i Ostatnim człowieku. Konflikt obu tych atawistycznych sił to, jak powtarza Fukuyama za Heglem, główna siła napędowa ludzkiej historii, wyznaczająca horyzont ludzkiej wolności. Walka o uznanie, godność, honor i prestiż (za którymi stoi thymos) nie oznacza jednak wolności w rozumieniu oświeceniowym (za którą z kolei stoi czynnik izotymiczny): więcej ma wspólnego z esencjalistycznymi określeniami wolności i godności człowieka. 
bezpieczeństwa a niepohamowanym pędem wolnościowym $)^{4}$, czy Samuel Huntington (konflikt międzycywilizacyjny) ${ }^{5}$, stawiamy i wyróżniamy tę powyższą, intelektualnej przede wszystkim natury (podczas, gdy tamte wykazują wyraźne związki z praktyką społeczną), to jakie przemawiają za tym racje? I dlaczego wreszcie widzieć $\mathrm{w}$ tym sprzeczność, a nie wzajem dopełniające się konstrukty myślowe? Wszystko to doprowadzić ma nas do kwestii zasadniczej dla całości podjętych tu rozważań, mianowicie do pytania o to, czy „rozstrzygnięcie” sporu o człowieka, w swoim świeckim wydaniu przechylające się wyraźnie na korzyść orientacji konstruktywistycznych (jeśli serio potraktować tezę, akceptowaną również często przez esencjalistów, że żyjemy w epoce ponowoczesnej i jesteśmy życiowymi postmodernistami), oznacza, jak chcą zwolennicy myślenia esencjalistycznego, stan pogłębiającego się permanentnie kryzysu, który my, zatroskani o conditio humana, winniśmy starać się na różne sposoby przezwyciężyć, np. próbując sięgać do rozwiązań znanych z przeszłości (przywracanie religii jej rozległego wpływu na życie zbiorowe, odnawianie pozycji nauk szczegółowych w domenie moralnej etc.; wszystko to wraz z nieuchronnie towarzyszącą tym procesom hierarchią znaczeń i dyscypliną duchowo-intelektualną)? Czy też jest może tak, jak chce strona przeciwna: wizja konstruktywistyczna to obiecujący projekt emancypacji człowie$\mathrm{ka}$, albo ujmując rzecz zgodnie z jej historycznym wymiarem - nieuchronne dopełnienie procesu zapoczątkowanego przez europejskie oświecenie, a szerzej jeszcze - odzwierciedlenie immanentnej logiki rozwoju człowieka na drodze jego coraz pełniejszej racjonalizacji i autonomizacji ${ }^{6}$ ? Logiki, której musi się oprzeć każde roszczenie do

$4 \quad$ W przeciwieństwie do Fukuyamy, Bauman wykazuje w opisie człowieka współczesnego większy pesymizm. „Świat ponowoczesny - czytamy w rozprawie na temat głównych wyznaczników tożsamości ponowoczesnej - przymierza się do ewentualności życia z niepewnością na stałe; do warunków na zawsze już niepewnych, i to taką niepewnością, jakiej zredukować żadną miarą się nie da." Z. Bauman, Ponowoczesność jako źródto cierpień, Warszawa 2000, s. 44.

„Najostrzejsze, najpoważniejsze i najgroźniejsze konflikty nie będą się w tym nowym świecie toczyć między klasami społecznymi, biednymi i bogatymi czy innymi grupami zdefiniowanymi w kategoriach ekonomicznych, ale między ludami należącymi do różnych kręgów kulturowych. [...] Najniebezpieczniejsze zaś są konflikty kulturowe na liniach granicznych między cywilizacjami." S. P. Huntington, Zderzenie cywilizacji, przekł. H. Jankowska, Warszawa 2000, s. 18.

6 Oczywiście, konsekwentny konstruktywizm, np. w wersji neopragmatystycznej, odrzuca możliwość poważnego traktowania ,praw rozwojowych” i innych podobnych, metafizycznych z ducha, konceptów. Cofają nas one, powiada się tam, do stadiów historii dla człowieka mniej zadowalających. Czy jest to konsekwentne 
sytuowania przesłanek ludzkiej podmiotowości i godności poza człowiekiem: w religii, metafizyce, paradygmacie scjentystycznym etc. Nauka Dopiero uznanie ludzkiej przygodności, zmienności i wieloznaczności jako nieusuwalnych składników człowieczego habitus, czyni projekt wolnościowy, uwikłany u swoich oświeceniowych podstaw w rozmaite metafizyczne aporie, prawdziwie realnym, to znaczy odpowiadającym rzeczywistej naturze człowieka. Oczywiście, takie myślenie nie wytrzymuje próby w zestawieniu z zasadami tradycyjnej logiki (biorąc choćby pod uwagę iluzję jego fundamentalnej bezzałożeniowości, uwidaczniającą się w tkwiącym w nim implicite przekonaniu o pozytywnym znaczeniu wolności), ale trzeba przecież zauważyć, że chodzi tu właśnie o wyłączenie spod zależności od wszelkich „pierwszych zasad", o samoregulującą się w duchu pragmatystycznym strukturę egzystencjalną, skłonną do kontentowania się wyznaczaniem sobie zadań niewykraczających poza horyzont praktycznej celowości, pobłażliwą dla własnej niekonsekwencji oraz sceptyczną wobec wszelkich prób absolutyzowania jakichkolwiek wartości (zwłaszcza w dziedzinie moralności i obyczaju $)^{7}$. Społeczeństwa przeniknięte tak rozumianym etosem wolnościowym, które określa się dziś mianem demokratyczno-liberalnych, ujawniają w tej mierze paradoksalne rozbieżności zasad i praktyki, wśród których jedna zwłaszcza zasługuje na baczniejszą uwagę ze względu na fakt, że zdaje się godzić w samą podstawę wolności. Chodzi o wspomniany sceptycyzm, który skłócony jest w praktyce z faktyczną absolutyzacją zasady wolnościowej i który daleko już, jak się zdaje, wykroczył poza zdroworozsądkowy postulat ograniczania wolności jej wrogom ${ }^{8}$. Wolno w tym widzieć szersze, choć przy tym

stanowisko w obliczu afirmacji pewnego stylu bycia i myślenia, to kwestia na oddzielne rozważenie.

7 Co ciekawe, sprzeczności logiczne projektu wolnościowego, nie uchodziły uwagi samym liberałom. Na przykład Bertrand Russell pisze nawiązując do doktryny praw człowieka: „Jest prawdą, że z filozoficznego punktu widzenia doktryna ta jest nie do obrony; ale $z$ historycznego i pragmatycznego punktu widzenia była użyteczna i obecnie cieszymy się wieloma swobodami, które pomogła wywalczyć.” B. Russell, Władza. Nowa analiza społeczna, przekł. M. Kądzielski, R. Gołębiewski. Warszawa 2001, s. 95.

„Przyjęcie historycznego uprzywilejowania liberalnej demokracji czyni [...] oczywistym [...] wniosek, że wszystko, cokolwiek istnieje w społeczeństwie, musi stawać się z czasem liberalno-demokratyczne i być przeniknięte duchem ustroju. Tak jak kiedyś w socjalizmie wszystko nosiło cechę socjalizmu i wszystkie najważniejsze określenia poprzedzane były przymiotnikiem „socjalistyczny”, tak teraz wszystko powinno być liberalne, demokratyczne lub liberalno-demokratyczne, a opatrzenie czegokolwiek lub kogokolwiek którymś z tych przymiotników powoduje natychmiastową nobilitację. Odmowa zaś takiego określenia 
bardzo swoistej natury, odzwierciedlenie sprzeczności między ponowoczesnym konstruktywizmem a tradycjonalnym esencjalizmem: gdy pierwszy programowo odżegnuje się od jakichkolwiek związków $\mathrm{z}$ absolutnymi zasadami, drugi dostrzega ich potwierdzenie w praktykach pierwszego. Jeśli rację mają krytycy demokracji liberalnej (vide przypisy nr 8 i 9), istniejący stan rzeczy rozstrzygałby spór na korzyść tradycjonalistów, w tej przynajmniej mierze, że praktyczną ważkość zachowywałoby ich przeświadczenie, że nie sposób utrzymać spójności projektu wolnościowego bez respektu dla jego esencjalistycznej filogenezy oraz bez zrozumienia jego absolutyzacyjnych tendencji i wynikających stąd zagrożeń; ceną zaś nieuwzględnienia tych zastrzeżeń pozostaje daleko posunięta hipokryzja. Wszelako możliwość przeniesienia sporu na płaszczyznę spekulatywnej deliberacji nie niesie z sobą poważniejszej nadziei konsensusu, i to nie tylko dlatego, że spór ów ma charakter fundamentalny, o czym niebawem powiemy, ale również dlatego, że samo pojęcie deliberacji zostało w tym przypadku przysposobione do potrzeb jednej ze stron, silniejszej, którą niewątpliwie jest środowisko określone tu przez nas umownym mianem konstruktywistycznego. A przysposobienie to polega na wspomnianej już absolutyzacji idei wolnościowej i, co z praktycznego punktu widzenia szczególnie doniosłe, roszczeniu do bycia tejże idei najwyższym depozytariuszem i strażnikiem ${ }^{9}$. W takich realiach ideał pluralizmu leżący

skazuje na degradacje moralną, surową krytykę intelektualną i historyczne unicestwienie.” R. Legutko, Triumf człowieka pospolitego, Poznań 2012, s. 36.

„Liberalizm jest przede wszystkim doktryną władzy. Jest to nie tyle teoria, ile superteoria społeczeństwa, to znaczy taka, która uznaje się za wyższą od innych w porządku logicznym. [...] jej cel - wedle poglądu zwolenników - stanowi stworzenie ogólnych ram, w których inni będą mogli działać. [...] Liberałowie do niedawna mówili, zapewne w dobrej wierze, że są doktrynalnie przezroczyści, ponieważ nie tylko nie wykluczają nikogo z wielkiego społeczeństwa, lecz chcą wszystkich do niego włączyć. Przypominają twórców kodeksu drogowego oraz tych, którzy ruchem drogowym kierują. Pragną stworzyć taki system dróg, po którym będzie się mogła poruszać maksymalnie duża liczba pojazdów, znacznie większa niż w przypadku innych twórców kodeksu drogowego i innych kierujących ruchem. Tylko oni - twierdzili - mogą taki system stworzyć, bo tylko oni są neutralnymi arbitrami skonfliktowanego świata. Ten szlachetny cel ma jednak swoją drugą stronę, zwykle przemilczaną przez liberałów uważających się za przezroczystych. Nie tylko stawiają się zawsze w pozycji wyższej, domagając się większej od innych władzy, lecz w zasadzie nigdy nie są usatysfakcjonowani posiadaną władzą i pragną jej coraz więcej. Chcą rządzić nie tylko w wielkim społeczeństwie, lecz także w jego wszystkich fragmentach; nie tylko w tym, co ogólne, lecz także w tym, co szczegółowe; nie tylko ludzkimi działaniami, lecz także ludzkimi myślami. [...] Liberałów uważających się za przezroczystych jest dzisiaj coraz mniej. Teraz większość traktuje liberalizm światopoglądowo, to znaczy jako światopogląd najadekwatniejszy do dzisiejszych czasów, który 
u podstaw koncepcji liberalnej może być postrzegany w kategoriach raczej konwencjonalnej ramy dla gier dyskursywnych, aniżeli warunek Nauka uczciwego, merytorycznego polilogu, powiększającego liczbę prawd powszechnie uznawanych i wznoszącego społeczną dojrzałość na coraz wyższy szczebel rozwoju, czego oczekiwali po przyszłości społeczeństw demokratycznych klasycy myśli liberalnej, tacy jak John Stuart Mill ${ }^{10}$.

Konstatacja ta dostarcza jednocześnie odpowiedzi na pytanie o istotność konfliktu dwu fundamentalnych wizji człowieczeństwa wywodzącego się ze zderzenia myśli konstruktywistycznej i esencjalistycznej. Otóż istotność tę wyznacza, jak się zdaje, emanacja rzeczonego konfliktu na rozległą sferę praktyk społecznych: tak dyskursywnych, jak politycznych czy obyczajowych; tutaj zaś podlega on transpozycji na szereg decyzji moralno-intelektualnych określających tożsamość człowieczeństwa naszego czasu. Jej dominujący dziś w świecie Zachodu typ, opisywany przez krytyków ponowoczesności, takich jak Bauman, wciela, co charakterystyczne, podstawowe roszczenia nurtu konstruktywistycznego. Poszukiwany z taką pieczołowitością przez intelektualistów nowożytnych związek „teorii” i „praktyki” („,norm” i „postaw” etc.) manifestuje się w tym przypadku postawą wyrażającą przeświadczenie, że wartość wszelkiej idei, w tym wolnościowej, wyznacza jej społeczna efektywność, a w ostatecznej konsekwencji - jej walor konsumpcyjny: w skrajnej wersji Baumanowskiej, kto nie konsumuje, ten społecznie nie istnieje. Możemy w tym widzieć, z jednej strony, potwierdzenie triumfu (lub co najmniej preponderancji) idei wolnościowej, uwalniającej człowieka z obligacji ograniczających jego horyzont życiowy do tożsamości zastanych a krępujących, z drugiej - przejaw jej konfudującej erozji, w tej przynajmniej mierze, w jakiej zachodzi rozbieżność między intencjami twórców projektu emancypacyjnego a jego praktyczną dziś realizacją.

Zanim zastanowimy się nad odpowiedzią na pozostałe pytania, warto już teraz zasygnalizować problem, w który wszystkie inne poruszane w niniejszym szkicu zlewają się niczym dopływy głównej rzeki.

stoi w opozycji do innych światopoglądów i musi z nimi wygrać.” R. Legutko, Triumf, s .133-134.

10 „W miarę rozwoju ludzkości ilość bezspornych i niewątpliwych doktryn będzie stale wzrastać i można prawie mierzyć pomyślnośćludzkości liczbąi doniosłością prawd, które nie są już zwalczane. Zaprzestanie poważnej polemiki w jednej kwestii za drugą jest jednym z koniecznych następstw ustalania się opinii ustalania się równie zbawiennego, gdy opinia jest prawdziwa, jak niebezpiecznego i szkodliwego w razie jej fałszywości.” J. S. Mill, O wolności, [w:] J. S. Mill, Utylitaryzm. O wolności, przekł. A. Kurlandzka, Warszawa, s. 142. 
Otóż jeśli główną osią sporu o człowieka nie jest już obecnie taki czy inny paradygmat człowieczeństwa wywodzony z określonej tradycji religijnej, filozoficznej czy politycznej (tak jak to było np. w przypadku konfrontacji antropologii chrześcijańskiej z marksistowską), lecz generalna przeciwstawność tendencji rozkładowych oraz afirmatywnych względem esencjalistycznych wyróżnień człowieka, to na czym właściwie polega niebezpieczeństwo, które skłania nas do wzmożenia troski o conditio humana; w którym punkcie człowiek, jakim go znamy z przeszłości (,dziecko Boże”, „miara wszechrzeczy”, zoon politikon, „podmiot dziejów” etc.), ponosi, faktycznie bądź potencjalnie, szwank największy? Oczywiście, liczba możliwych odpowiedzi jest tutaj długa, ale jednej pominąć nie sposób, bez ryzyka banalizacji sprawy. Chodzi o kwestię godności ludzkiej, która - jako być może jedyna - zachowuje swój niepokojąco metafizyczny wydźwięk również na gruncie rozważań konstruktywistycznych, uświadamiając tym samym istnienie pewnej subtelnej granicy rozdzielającej antyesencjalistyczną kampanię konstruktywizmu na dwa etapy: linearny i systemowy oraz wielokierunkowy i indywidualistyczny. Walka z przesądem, kultywacja racjonalności, projekcje multikulturalizmu społecznego należą niewątpliwie do etapu pierwszego, natomiast instrumentalizacja prawa do życia, deregulacja normatywności płciowej czy osobowej - do etapu drugiego.

Dwie rzeczy zasługują przy tym na szczególną uwagę: 1) niebezpieczeństwo, że po przekroczeniu wspomnianej granicy wszelka relatywizacja pojęciowa doprowadzi do bardzo wymiernej i wieloaspektowej komplikacji społecznej (np. w świetle niejednoznaczności kwestii godnościowej, dramatyzacji ulega problem zbędności osób nieproduktywnych gospodarczo, wykluczonych, chorych, ułomnych etc.) oraz 2) notoryczna wieloznaczność pojęcia godności ludzkiej. Jak słusznie zauważa Eduard Picker ,powszechnym uznaniem za absolut godność człowieka cieszy się tylko «jako taka». Jej treść jest natomiast w najwyższym stopniu niejasna i sporna"11. Właśnie w tym obszarze topiące moce konstruktywizmu natrafiają na punkt kłopotliwy i paradoksalny. $\mathrm{Z}$ jednej bowiem strony, takie idee, jak godność człowieka, podobnie jak prawa człowieka, gotowe byłyby potraktować z równym brakiem pobłażliwości, co „pierwsze zasady”, „nieskończoność”, „absolut”, „prawa historii”, a nawet „postęp”, nie mówiąc już o Lyotardowskich wielkich narracjach: jako sfunkcjonalizowane dla pewnych ludzkich potrzeb i celów abstrakcje, zależnie od okoliczności użyteczne lub

$11 \quad$ E. Picker, Godność człowieka a życie ludzkie. Rozbrat dwóch fundamentalnych wartości jako wyraz narastajacej relatywizacji człowieka, przekł. J. Merecki. Warszawa 2007, s.8. 
będące źródłem opresji, zawsze wszelako aspirujące - niepotrzebnie i niezasadnie zdaniem konstruktywistów ze szkoły neopragmaty- Nauka stycznej - do statusu bytów poza - lub ponadludzkich, a to z powodu posiadania jakoby pewnego niezbywalnego jądra semantycznego, odpornego na działanie czasu czy niezgodność ludzkich mniemań. $\mathrm{Z}$ drugiej jednak strony, w różnych odmianach myśli konstruktywistycznej, zwłaszcza zaś w jej wariancie liberalnym, mamy do czynienia $\mathrm{z}$ manifestowanym jawnie respektem dla pojęcia godności człowieka. Fukuyama np. widzi tu nawet przejaw religijnej z ducha afirmacji.

Pogląd o równej godności ludzkiej - pisze wielki piewca demokracji liberalnej - oderwany od swoich chrześcijańskich czy kantowskich korzeni, jest prezentowany z mocą dogmatu religijnego nawet przez największych materialistów wśród przyrodników ${ }^{12}$.

Tenże sam Fukuyama uzasadnienia dla godnościowego aksjomatu szuka w izotymicznym (dotyczącym pragnienia uznania) pierwiastku natury ludzkiej. Trudno jednak powiedzieć, by to, do czego dochodzi było nawet dla samych liberałów bardziej przekonujące aniżeli chrześcijańska koncepcja dziecka Bożego, którą w swoim czasie zsekularyzowali do postaci autonomicznego indywiduum. Pisze bowiem autor Końca człowieka:
Żądanie równego uznania wskazuje, że kiedy odsuniemy na bok wszyst- kie akcydentalne cechy człowieka, pozostanie nam pewna esencja człowieczeństwa, warta pewnego minimalnego szacunku - nazwijmy ją czynnikiem X. Kolor skóry, wygląd, klasa społeczna czy bogactwo, płeć, kultura, czy nawet wrodzone talenty są akcydentalnymi cechami, których nie uznajemy tu za esencję. [...] Czynnik X to esencja czło- wieczeństwa, najbardziej podstawowy sens bycia człowiekiem. Jeżeli wszystkie istoty ludzkie są obdarzone równą godnością, czynnik X musi być ich wspólną, powszechną cechą ${ }^{13}$.

Z kolei dla innego współczesnego apostoła myśli wolnościowej, Richarda Rorty'ego, rzecz nie jest w ogóle warta dyskusji. Jeśli już powinniśmy przejmować się jakimiś pojęciami (wartościami), to najlepiej takimi, które mają związek z poprawianiem naszych relacji $\mathrm{z}$ innymi ludźmi, a generalnie - z liberalnym rozumieniem lepszego życia. W istocie rzeczy z takimi, które składają się na moralno-obyczajowy kanon społeczeństwa konsumpcyjnego w typie zachodnim.

12 Uściśla równocześnie, że „trwający spór o status moralny istot nienarodzonych [...] jest jedynym wyjątkiem od tej ogólnej zasady.” F. Fukuyama, Koniec cztowieka. Konsekwencje rewolucji biotechnologicznej, przekł. B. Pietrzyk, Kraków 2004, s. 205. 
Dla samego Rorty'ego są to w szczególności otwartość, ciekawość, gotowość do zmian. Jedynym akceptowalnym kryterium oceny tych pojęć pozostaje w zasadzie użyteczność; tradycyjnie pojmowana „słuszność”, normatywność, zgodność z jakkolwiek pojętym kodeksem praw naturalnych i (lub) Boskich, zostają przez rortian odrzucone do lamusa jako beznadziejnie anachroniczne. „Dyskutować - powiada Rorty - o użyteczności danego zestawu tworów społecznych określanych przez nas «prawami człowieka», to dyskutować kwestię tego, czy społeczeństwa inkluzywne są lepsze od ekskluzywnych"14. Zgodnie z tym, co zostało przedstawione powyżej na temat użyteczności, nie ma lepszego sposobu na ustalenie różnicy między poszczególnymi wartościami (nawet w sytuacji, gdy jedna uświęcona jest wielowiekową tradycją, a druga jawi się przez swoje nowatorstwo jako ekscentryczna), aniżeli przyjrzenie się ewentualnym praktycznym skutkom, jakie wynikałyby z uobywatelnienia jednej oraz drugiej w życiu liberalnej wspólnoty. Toteż ,pojęcie «niezbywalnych praw człowieka» nie jest ani lepszym, ani gorszym sloganem niż «posłuszeństwo woli Bożej»"15. Mówić przeto „o prawach człowieka to tłumaczyć swe działania poprzez utożsamienie się ze wspólnotą osób myślących podobnie - uznających dany sposób postępowania za całkiem naturalny"16. Różnica między dawnymi koncepcjami człowieka, grecką i chrześcijańską a nowymi, liberalną i konstruktywistyczną, „to różnica między zamknięciem a otwartością, między poczuciem bezpieczeństwa, które daje niezmienność a [...] romantyzmem nieprzewidywalnej zmiany" ${ }^{17}$.

Rzut oka na neopragmatyzm, najbardziej radykalną obecnie przy całej swojej intencjonalnej łagodności inkarnację ducha emancypacji, uzmysławia trudność, z jaką musi mierzyć się orientacja, która na potrzeby szkicu została określona jako esencjalistyczna (właściwie jest to konglomerat orientacji, o czym niebawem). W języku potocznych rozróżnień pojęciowych trudność tę utożsamia się zwykle z zagrożeniem relatywizmem. Może jednak, nawiązując do pytania zadanego już wcześniej, bać się nie ma w gruncie rzeczy czego. Może ponowoczesna transpozycja idei wolnościowej zwiastuje czasy dla kondycji ludzkiej pomyślniejsze, niż mogłoby to wynikać z rozpoznań sytuacji dokonywanych przez „esencjalistów”? A wreszcie, może mamy tu do czynienia nie z żadną sprzecznością określającą „ducha czasu”, tylko

14 R. Rorty, Etyka bez zasad, [w:] R. Rorty, Filozofia a nadzieja na lepsze społeczeństwo, przekł. J. Grygieńć, Toruń 2013, s. 138.

15 Tamże, s. 136.

16 Tamże, s. 137.

17 Tamże, s. 141. 
ze swego rodzaju dialektycznym dopełnianiem się dwóch głęboko z sobą powiązanych projektów humanistycznych? Zanim wyciągniemy Nauka stosowne wnioski, przyjrzyjmy się jeszcze, pobieżnie z konieczności, pewnym dodatkowym, historycznym i fizjonomicznym, rysom obu naszych dyskursywnych antagonistów.

Konflikt będący przedmiotem naszego namysłu, zbanalizowany już może nieco w swoich wersjach potocznych (normatywizm vs relatywizm, konserwatyzm vs nowoczesność, tradycjonalizm vs modernizacja etc.), oznacza na pewnym poziomie uogólnienia przewrót umysłowy czyniący światy, których dotyczy - przeszły i obecny - z gruntu sobie obcymi. Stanie się to jaskrawo widoczne, gdy nasze zagadnienie umieścimy w perspektywie historycznej obejmującej nowożytność zarówno przed- jak pooświeceniową. Zobaczymy wówczas, że doprowadzona do ostatecznych konsekwencji w neopragmatyzmie amerykańskim i dekonstrukcjonizmie Derridiańskim batalia między „konstruktywizmem” a „esencjalizmem” wiedzie do unieważnienia ambitnych projektów osadzenia idei człowieczeństwa, w jej wymiarze aksjologicznym (choć nie tylko w nim, rzecz jasna), na fundamentach innych aniżeli religijne, jakkolwiek z założenia równie, a może nawet bardziej niż religijne, pewnych i trwałych. Budulca w tej mierze najsolidniejszego miała dostarczać nauka nowożytna, z jej wiarą w racjonalną współzależność wiedzy i moralności oraz wyrosłym z tej wiary postulatem pragmatycznej organizacji życia zbiorowego, co w danym przypadku skutkowało generalną niechęcią do odziedziczonych po przeszłości form relacji społecznej, które uważano za irracjonalne oraz waloryzacją relacji motywowanych utylitarnie. W dziedzinie realnych procesów społecznych odpowiednikiem było Tönniesowskie przejście z Gemeinschaft do Gesselschaft. Wsparciem dla nauki na drodze tak pojętej sekularyzacji miała być szeroko rozumiana tradycja humanistyczna, wywodzona najczęściej od starożytnych Greków i Rzymian; warto przy tym odnotować, że znaczenie jej komponentu chrześcijańskiego było w narracjach świeckich coraz bardziej pomniejszane aż do zupełnego niemal wykluczenia ${ }^{18}$. Rzeczą charakterystyczną dla wczesnej

$18 \quad$ Zwraca na to uwagę np. przywoływany już Fukuyama: „Wartości podzielane przez całą współczesną liberalną demokrację stają się w coraz większym stopniu nie religijne, lecz polityczne. Był czas, kiedy to ogromna większość Amerykanów zgodziłaby się określić swe państwo jako „kraj chrześcijański”. Dziś zgodziłaby się z tym znaczna mniejszość obywateli i to mniejszość, której reszta społeczeństwa przygląda się z nieufnością. W znacznej większości Amerykanie woleliby widzieć naturę swego społeczeństwa w kategoriach świeckich wartości, takich jak demokracja, równość wobec prawa i rządy konstytucyjne. [...] Zważywszy sekularyzację wielu europejskich społeczeństw, rzecząjeszcze bardziej osobliwą 
i środkowej fazy sekularyzacji (obejmujących okres od oświecenia do modernizmu) była próba separacji głównych nurtów tradycji humanistycznej i formującego się paradygmatu scjentystycznego i traktowania ich jako wzajem niezależnych, choć w zasadniczym swoim przeznaczeniu użytecznych narzędzi wzmocnienia statusu moralnego człowieka jako istoty wyróżnionej w Kosmosie. Świadomość istnienia kluczowych paradygmatów człowieczeństwa, wywodzących się z trzech przywołanych źródeł: greckiego, chrześcijańskiego i przyrodoznawczego była powszechna i zasadniczo nie budziła sprzeciwu. Jeszcze w latach 20. ubiegłego wieku Max Scheler pisał:

Jeśli zapytać wykształconego Europejczyka, co sobie myśli w związku ze słowem „człowiek”, to prawie zawsze zaczynają w jego głowie konkurować wzajemnie trzy zupełnie nie dające się ze sobą pogodzić kręgi myślowe. Po pierwsze, krąg myślowy tradycji żydowsko-chrześcijańskiej, [mówiącej] o Adamie i Ewie, stworzeniu, raju i upadku. Po drugie, antyczno-grecki krąg myślowy, w którym po raz pierwszy w świecie samoświadomość człowieka zdobyła się na pojęcie jego szczególnego stanowiska (Sonderstellung), [co znalazło wyraz] w tezie, że człowiek jest człowiekiem dzięki temu, iż ma „rozum”, logos, phronesis, ratio, mens, [przy czym] logos oznacza tu zarówno mowę, jak zdolność uchwycenia ,istoty” (,Was”) wszelkich rzeczy; z poglądem tym ściśle wiąże się koncepcja, że u podstaw całego Wszechświata tkwi nadludzki rozum, w którym spośród wszystkich istot uczestniczy jedynie człowiek. Trzeci krąg myślowy stał się od dawna tradycyjnym kręgiem nowożytnego przyrodoznawstwa i psychologii genetycznej [utrzymujących], że człowiek jest bardzo późnym, końcowym rezultatem rozwoju ziemskiej planety, jest istotą różniącą się od swoich przodków w świecie zwierząt jedynie stopniem skomplikowania mieszanin energii i zdolności, które jako takie występują już w przyrodzie stojącej niżej od człowieka. Owych trzech kręgów myślowych niepodobna połączyć w jedną całość ${ }^{19}$.

W sytuacji obecnej, niemal sto lat po powyższych słowach, mamy do czynienia z całkowitą deregulacją tego podziału. Wszystkie projekty

byłoby mówić o współczesnej Europie jako o «obszarze chrześcijańskim». Jakkolwiek chrześcijaństwo okazało się niezwykle istotne w procesie tworzenia cywilizacji europejskiej, to jednak współcześni Europejczycy mają skłonność określać swą tożsamość kulturową znacznie częściej w kategoriach politycznych niż religijnych. Ci, którzy czynią to w kategoriach religijnych - jak na przykład różnorodne społeczności bałkańskie - wydają się dziś zdumiewającym przeżytkiem, pochodzącym ze znacznie wcześniejszych wieków naszej historii.” F. Fukuyama, Wielki Wstrzas. Natura ludzka a odbudowa porzadku społecznego, przekł. H. Komorowska, K. Dorosz, Warszawa 2000, s. 218.

$19 \quad$ M. Scheler, Stanowisko człowieka w kosmosie, [w:] tenże, Pisma $z$ antropologii filozoficznej i teorii wiedzy, przekł. S. Czerniak, A. Węgrzecki, Warszawa 1987, s. 46-47. 
antropologiczne, o jakich wspomina Scheler, zostały poddane upłynnieniu, podobnie jak granice między nimi, i zlały się w swoistą domenę Nauka myśli zachowawczej (staromodnie, zdaniem adwersarzy, konserwatywnej), dezawuowaną coraz śmielej przez siły, któreśmy określili, operując na bardzo wysokim poziomie abstrakcji, jako siły emancypacji. Rozbrat z metafizyczną przeszłością człowieka, owo - jak to nazywa Odo Marquard - „rozstanie z filozofią pierwszych zasad”, prowadzi w przekonaniu jego autorów i sympatyków nie tylko do poszerzenia sfery ludzkiej autonomii i wolności: stanowi również o rzeczywistej afirmacji człowieka, w odróżnieniu od niepełnej lub zgoła fałszywej, jaka miała płynąć z antropologii motywowanych religijnie. Wreszcie, nowa antropologia zwraca uwagę na okoliczność w tradycyjnych koncepcjach człowieczeństwa notorycznie niedocenianą albo zgoła pomijaną: przyrodzona niedoskonałość człowieka, immanentna wieloznaczność jego myśli i działań, wewnętrzna niespójność i kontyngentność jego egzystencji, stawiają go w stosunku do kodeksów etycznych opartych na esencjalistycznych podstawach w położeniu co najmniej problematycznym. Człowiek, głosi się tutaj, jest czymś zarazem więcej i mniej, niż mogłoby wynikać z reguł, które ustanowił sobie w przeszłości.

Dążenie do pozycji absolutnych - pisze Marquard - wszystko jedno, czy chodzi o pozycję absolutnego podmiotu, absolutnego dyskursu czy absolutnego twórcy historii, jakim człowiek miałby być, przekracza ludzkie siły. W dodatku, aby przyjąc tę absolutną postawę, trzeba odwrócić wzrok od jakiejś części rzeczywistości człowieka - od jej najważniejszej części - trzeba o niej zapomnieć: fiat utopia, pereat homo. Pomija się to, co ludzkie, do czego przecież należy także to, co arcyludzkie ${ }^{20}$.

Można powiedzieć, że następstwem wspomnianej deregulacji było to, że filozofia, nauka i religia, znalazły się na wspólnej ławie oskarżonych, niekoniecznie sobie tego życząc i niekoniecznie będąc tego świadomymi. Rolę trybunału oskarżycielskiego i składu orzekającego przejęła tymczasem Wolność. Niegdyś cicha i szlachetna przewodniczka oświeconych umysłów, dziś hałaśliwa i bezwzględna despotka domagająca się posłuchu od każdego. Zwróćmy uwagę na owo nieuprawnione zawłaszczenie dwóch rozdzielonych w normalnej praktyce jurydycznej funkcji - okaże się ono ważną przesłanką dla naszych wniosków końcowych.

W istniejącym stanie rzeczy nie wypada filozofom, ani uczonym, nie mówiąc już o kapłanach, manifestować przesadnie poważnego

$20 \quad$ O. Marquard,Śmiechjest mata teodycea. Odo Marquard wrozmowie ze Steffenem Nietzschem, [w:] O. Marquard, Apologia przypadkowości, przekł. K. Krzemieniowa, Warszawa 1994, s. 154. 
stosunku do swoich obowiązków jako depozytariuszy pewnych społecznych przesłań (nie mówiąc o rolach depozytariuszy prawd), bez narażenia się na zarzut bycia wrogami wolności. Wolność w warunkach ponowoczesności źle bowiem znosi powagę i jednoznaczność, obowiązki i prawdy, za wyjątkiem tych - co notorycznie umyka uwadze jej najgorliwszych stronników - które sama firmuje.

Smutną nauką jest każda filozofia - powiada Marquard, jeden z rzeczników ponowoczesnego stylu filozofowania - która nie potrafi o tej samej rzeczy pomyśleć raz tego, raz czego innego i skłaniać do dalszego myślenia. W tym sensie podejrzany jest nawet wszelki pomysł, niech żyje wielomyśl. Należy ponownie dopuścić wiele historii: rzecz dobrze pomyślana, to już w połowie opowiedziana; kto chce myśleć jeszcze lepiej, powinien raczej opowiadać całość: filozofia musi ponownie mieć możność opowiadania, płacąc za to - oczywiście - swoją cenę: uznaniem $\mathrm{i}$ tolerowaniem własnej kontyngencji ${ }^{21}$.

Nie mając wystarczającego oparcia w świecie nauki i refleksji filozoficznej ${ }^{22}$, grecko-chrześcijański ideał człowieczeństwa, broni się już tylko - zgodnie z niezwykle trafnym spostrzeżeniem Pickera - mocą paradoksu swojej wieloznaczności i nieokreśloności. Najlepiej widoczne jest to w rozbudowanych dziś monstrualnie w świecie zachodnim praktykach jurydycznych.

Owe symptomy współczesnej niepewności aksjologicznej - zauważa Picker - uzasadniają podejrzenie, że sztywna absolutyzacja ochrony „godności” w porządku prawnym, który opiera się na rachunku i negocjacjach, jest możliwa tylko dlatego, że niejasność pozostawia obszerne pole do interpretacji. Takie wyniesienie godności otwiera po cichu duże możliwości wartościowania i kompromisu, a wraz z nimi ową „praktyczną konkordancję”, którą się w dziedzinie ochrony godności człowieka oficjalnie wyklucza ${ }^{23}$.

Podnoszone już w ramach tych rozważań ryzyko relatywizmu pojęciowego, pociągającego za sobą bardzo niepożądane społecznie następstwa (ograniczenie prawa do życia, erozja solidaryzmu społecznego, zanik standardów wiedzy i obyczajów etc.), przez część intelektualistów uważane jest za wyolbrzymione lub nawet podnoszone niepotrzebnie, skoro relatywizacja jest konieczną i wcale nie najbardziej dokuczliwą (dla rortian nawet pożądaną) ceną wolności; przez

\footnotetext{
$21 \quad$ Tamże, s. 118.

22 Biorąc pod uwagę relatywnie niewielki bezpośredni wpływ religii na życie społeczeństw zachodnich, wyłączamy ją z tego akurat wyliczenia, nie zapominając wszelako o wielorakim wpływie pośrednim.

${ }^{23} \quad$ E. Picker, Godność człowieka a życie ludzkie..., dz. cyt., s. 8-9.
} 
inną zaś część z kolei, przeciwnie - za eksponowane z niedostateczną powagą i zaangażowaniem. Dla Jana Pawła II i niektórych myślicieli Nauka związanych z prawicą polityczną (patrz przypisy nr 8 i 9), ryzyko relatywizmu to - toutes proportions gardées - ryzyko zakamuflowanego totalitaryzmu.

Dziś zwykło się twierdzić - pisze papież w encyklice Centesimus annus diagnozującej, między innymi, sytuację po zwycięstwie demokracji zachodniej nad komunizmem - że filozofią i postawą odpowiadającą demokratycznym formom polityki są agnostycyzm i sceptyczny relatywizm, ci zaś, którzy żywią przekonanie, że znają prawdę, i zdecydowanie za nią idą, nie są, z demokratycznego punktu widzenia, godni zaufania, nie godzą się bowiem z tym, że o prawdzie decyduje większość, czy też, że prawda się zmienia w zależności od zmiennej równowagi politycznej. W związku z tym należy zauważyć, że w sytuacji, w której nie istnieje żadna ostateczna prawda, będąca przewodnikiem dla działalności politycznej i nadająca jej kierunek, łatwo o instrumentalizację idei i przekonań dla celów, jakie stawia sobie władza. Historia uczy, że demokracja bez wartości łatwo się przemienia w jawny lub zakamuflowany totalitaryzm ${ }^{24}$.

Rodzi się nieodparcie pytanie: dlaczego filozofowie i ludzie nauki tak łatwo utracili pewność siebie lub - ujmując rzecz łagodniej i z uwzględnieniem heroizmu najbardziej niepokornych spośród nich - wiarę we własne znaczenie? Dlaczego z tak widocznym fatalizmem oddali pole sceptykom? Dlaczego myślenie utopijne, systemowe, metafizyczne wreszcie stało się dla nich samych synonimem niepoprawnego idealizmu, którego przejawy człowiek światły, by nie narazić swojej reputacji jednostki myślącej, winien skwapliwie w sobie tłumić? Podobne pytania można by odnieść do wielu środowisk związanych, instytucjonalnie bądź ideowo, z chrześcijaństwem, podkreślając w tym wypadku dodatkowo coraz bardziej zauważalną chwiejność i niekonsekwencję w odniesieniu do kwestii ochrony życia ludzkiego. W rezultacie żadna koncepcja człowieczeństwa, ani żadne z fundamentalnych praw ludzkich (wliczając tu najważniejsze $\mathrm{z}$ nich - prawo do życia) nie wydaje się dziś - przynajmniej w domenie świeckiej - solidnie ugruntowana, ani należycie zabezpieczona przed destrukcyjną dezawuacją. Oczywiście, dotyczy to wszystkich projektów o podobnym, metafizycznym i holistycznym, ukierunkowaniu.

Odpowiedzi należy prawdopodobnie szukać w konfudującym doświadczeniu wielości. Człowiek wystawiony na działanie rozmaitych

24 Jan Paweł II, Encyklika Centesimus annus z $1991 \mathrm{r}$. Tekst dostępny na stronie: http://www.opoka.org.pl/biblioteka/W/WP/jan_pawel_ii/encykliki/centesimus_2.html\#m4 (dostęp: 27.08.2014 r.). 
obrazów świata, a jednocześnie poddany presji tolerowania ich wszystkich jako równouprawnionych, rzadko potrafi wykazać się odwagą i niezależnością sprzyjającą zachowaniu własnych prawd w ich czystej, nieskażonej postaci. Wymaga to, jak się wydaje, kwalifikacji duchowych znacznie wykraczających poza przeciętność, toteż trudniej dziś wyciągać konsekwencje z człowieczej niekonsekwencji ${ }^{25}$. Dodatkowo jeszcze, pozbawiony stałych odniesien, w postaci Boskich zasad, wiecznych praw, czy dawnej wspólnoty (postulowana przez postmodernistów wspólnota liberalna wydaje się, póki co, kategorią zbyt ogólną i zbyt nieokreśloną, by można uznawać ją za odniesienie realne ${ }^{26}$ ), najbardziej sensowny sposób tak ochrony swoich życiowych interesów, jak zabezpieczenia osobowej integralności, znajduje człowiek współczesny w kultywacji własnego indywidualizmu. W semantyce wyrazu ,znajduje" należy podnieść jego umowność, bo samookreślenie człowieka nie jest w tym przypadku przecież efektem uświadomionego wyboru, lecz uczestnictwa w określonym typie kultury: o tożsamości nie przesądza tutaj zastana formacja duchowo-intelektualna, lecz płynna dynamika potrzeb indywidualnych i jej zagrożeń, do której jednostka może się mniej czy bardziej udatnie dostosować. Pisze o tym wszystkim z właściwą sobie przenikliwością Bauman:

Dzisiaj wzorce i porządki nie są już „dane”, a tym bardziej „oczywiste”. Jest ich zbyt wiele; zderzają się z sobą, a ich przykazania przeczą sobie wzajemnie, co pozbawia je nieodpartej, zniewalającej siły. Zmieniły swój charakter i zaczęły być postrzegane stosownie do owej zmiany: jako pozycje $\mathrm{w}$ indywidualnym spisie zadań do wykonania. [...] W efekcie mamy dziś do czynienia ze zindywidualizowaną i sprywatyzowaną wersją nowoczesności, w której obowiązek kreowania wzorców oraz odpowiedzialność za porażkę spoczywają przede wszystkim na barkach poszczególnych jednostek ${ }^{27}$.

Doniosłość faktu stopienia się tradycyjnych paradygmatów człowieczeństwa w jeden wielki konglomerat stronnictw (badawczych, religijnych, politycznych, artystycznych etc.) roszczących sobie prawo do posługiwania się dawnymi, esencjalistycznymi sposobami uzasadniania, dowodzenia, negowania etc., polega na tym, że wraz

$25 \quad$ Modne dziś, nacechowane przewrotnością, wyrażenia oksymoroniczne w rodzaju „konsekwentnej niekonsekwencji”, ,tyranii wolności”, ,siły bezsilnych”, ,wielości prawd”, „faktów jako interpretacji”, wydają się oddawać ducha opisywanych tu zjawisk.

26 To, co określane jest dziś mianem wspólnoty liberalnej, wspólnoty ludzi wolnych etc., odnosi się raczej do konkretnych środowisk opiniotwórczych, niźli do jakiegokolwiek z istniejących społeczeństw tout court.

27 Z. Bauman, Ptynna nowoczesność, przekł. T. Kunz, Kraków 2006, s. 14-15. 
z nim zanikł ów swoisty efekt synergii, jaki rodziło niegdyś wzajemne wsparcie, którego paradygmaty te mogły sobie udzielać - nierzadko Nauka nieświadomie - w dziedzinie obrony ludzkiej wyższości nad naturą, ludzkiej godności, niepowtarzalności etc. Gdy np. zawodziły scjentystyczne metody ratowania człowieka przed nieodwołalnym rozpłynięciem się w odmętach darwinizmu (poprzez przyznawanie mu jakichś akcydentalnych wyróżnień w rodzaju wysokiej inteligencji, systemów komunikacji wewnątrzgatunkowej, postawy wyprostowanej etc.), w sukurs przychodziła filozofia z jej antycznym ideałem rozumu bądź nowożytnym deizmem. Gdy z kolei staromodny sokratejsko-kartezjański racjonalizm uginał się pod ciosami modernistycznego przewartościowania wszystkich wartości, na pomoc szła mu nauka z jej nieodpartym autorytetem szafarki prawdy o człowieku i świecie, do której nieodmiennie należy ostatnie słowo. Oczywiście, zawsze na podorędziu pozostawała doktryna Kościoła z jej wizją dziecka Bożego i Odkupienia, z pojęciami wolnej woli, światła sumienia i powołania do życia wiecznego.

W rezultacie człowiek stał się nagi i bezbronny, już nie tylko teoretycznie, ale - odkąd ideologii wolnościowej podporządkowane zostało prawo i obyczaj - również praktycznie. W tej sytuacji ratunkiem nie mogła już być niezawodna, do niedawna, instancja odwoławcza w postaci pojęcia godności ludzkiej, skoro i ono wydrążone zostało z wszelkiej semantyki („,czynnik X” Fukuyamy).

$\mathrm{Z}$ odsieczą miały przyjść tym razem wyobraźnia i nieskończoność, zmieszane w olbrzymim tyglu konceptualnym znanym powszechnie pod mianem postmodernizmu. Wyobraźnia miała wyzwolić moce kreacyjne człowieka na skalę dotąd nieznaną, wyprowadzając ducha wolności poza granice, które go dotąd jeszcze tu i ówdzie krępowały. Granice wyznaczane przez zasady celowości i prawdopodobieństwa, dobrego smaku i przyzwoitości. A nieskończoność? Czymże jest, można zapytać, wyobraźnia bez nieskończoności? Nieskończoność miała być w tej odnowionej formule przedsięwzięcia emancypacyjnego (bo i tak m.in. powinniśmy o postmodernizmie myśleć) permanentną utopią, ekscytującą przez swoją nieokreśloność i do ciągłego ironizowania przez swoją nieziszczalność skłaniającą; utopią, w której wszystko jest możliwe i nic nie jest na serio.

Programowa wieloimienność postmodernizmu (jednym z najważniejszych artykułów postmodernistycznego credo pozostaje przekonanie o własnej idiomatyczności i niemożności stworzenia zadowalającej definicji postmodernizmu), brak jakichkolwiek wiążących reguł, tak estetycznych, jak intelektualnych, doskonale chroniły przed zarzutem 
niekonsekwencji, niespójności wewnętrznej czy błędu. Nie miał być przy tym postmodernizm, tak jak niegdysiejszy sceptycyzm filozoficzny, samoograniczającym przez swą jednostronność narzędziem intelektu, lecz pełnokrwistą zasadą życia, obejmującą wszystkie jego sfery, od mody, poprzez politykę i sztukę, do nauki i filozofii (określenie, które wydaje się oksymoronem - nauka postmodernistyczna - nie przestaje cieszyć się $\mathrm{w}$ pewnych kręgach intelektualnych prawem pełnego obywatelstwa).

Jak już zostało wspomniane wcześniej, w postmodernizmie spotykają się oba wielkie ruchy myśli, które rozpatrujemy: jeden upłynniający wszystko na swojej drodze niczym lawa, nieliczący się z żadnymi tradycjami, z żadnymi stałymi układami odniesień; owszem, gotów jest z nich czerpać i nawet wznosić z czerpanych elementów rozmaite konstrukcje (stąd metaforyczne określenie go mianem „konstruktywizmu”), ale zawsze na użytek celów doraźnych, nigdy uniwersalnych; drugi ruch, mający mniej czy bardziej rozbudowane poczucie zależności od praw, które uważa za niezależne od siebie, zakotwiczony w rzeczywistości za sprawą wiary w prawomocność takich pojęć jak: „natura ludzka”, „prawa Boskie”, „natura (istota) rzeczy”, „pierwsze zasady”, „prawa człowieka”, „prawa naturalne”, ,prawda obiektywna”, „fakty społeczne”, ,prawa naukowe" etc. Ruchy te, z filozoficznego punktu widzenia fundamentalnie sprzeczne, w postmodernizmie miały ulec dyfuzji, doznając w ten sposób mimowolnego pojednania (lub raczej unieważnienia). Miało być to możliwe, i zdaniem postmodernistów stało się faktycznie możliwe, m.in. dzięki temu, że sprzeczność - wyzbyta swoich gnoseologicznych oraz logicznych uwikłań - przybrała w postmodernizmie charakter kategorii estetycznej, podobnie jak ironia. To, że istnieją zjawiska niedające się pogodzić, wykluczające się, ba, nawet zwalczające się wzajemnie, lecz zmuszone jednocześnie do współistnienia, jest dla postmodernizmu jednym z paradoksów rzeczywistości, które ten przyjmuje za normalny jej stan i które wykorzystuje - najczęściej w literaturze i sztuce - do uprawiania swoich ,gier językowych".

Człowiekowi, w zamian za zrzeczenie się przezeń jego tradycyjnych prerogatyw, moralnych i poznawczych, oferował postmodernizm uczestnictwo we wspólnocie demoliberalnej. Miał w niej człowiek znaleźć nowe, inne aniżeli w systemach metafizycznych i religijnych, źródło dowartościowania. Było nim prawo do nieograniczonej autokreacji, swobodnej ekspresji, a w ostatecznym rozrachunku - wymiany tożsamości. Nie była to jednak transakcja do końca uczciwa (a już na pewno nie była intelektualnie klarowna), albowiem opierała się na iluzji naturalnego pokrewieństwa liberalizmu i postmodernizmu. Uzdolnienie 
do wolności i wyobraźnia to dla postmodernistów, zwłaszcza artystów tego nurtu, naturalnie przyciągające się atrybuty człowieczeństwa, od- Nauka dające przy tym unikalność człowieka w naturze; jedna bez drugiej nie istnieje. Szacowne pojęcie wolności, pielęgnowane i rafinowane przez pokolenia liberałów, miało tutaj, jak się wydaje, służyć legitymizacji ekscesów postmodernistycznej wyobraźni, chroniąc ją w ten sposób przed zarzutem anarchii. Wolność jest dobra, więc czerpmy z niej, na ile nas stać - można by przeczytać w postmodernistycznym dekalogu, gdyby powstał. Zakres wspólnoty jest w tym wypadku, jak zauważa Ryszard Legutko, ograniczony.

Liberalizm - pisze polski filozof - popełnia grzech główny, jaki postmoderniści nie mogą mu wybaczyć: nie akceptuje on bezpodstawności. Nie tylko pewni liberałowie są entuzjastycznymi apologetami konkretnych struktur instytucjonalnych - na przykład, wolnego rynku - i nie mają najmniejszej ochoty na ironiczne dystansowanie się od niego, ale cały liberalizm jako teoria opiera się na bezwzględnej podstawie, którą jest racjonalna jednostka ludzka. Człowiek liberalny szczyci się tym, iż potrafi posługiwać się rozumem bezwzględnym, nie uwikłanym ani w historię, ani w kulturę; dlatego jest on zdolny wydawać uniwersalistyczne oceny i stosować się do uniwersalistycznych norm. Wierzy w „naturę”, „istotę”, ,powszechne uprawnienia”, ,argument”, „obiektywny osąd”, i w wiele innych rzeczy, które według postmodernisty należą do groźnej epoki archaicznej. Człowiek postmodernistyczny natomiast jest zawsze uwikłany w jakąś „grę językową” i zawsze działa jako członek pewnej „interpretującej wspólnoty”. Ponieważ przyjęcie perspektywy absolutnie zewnętrznej oraz znalezienie ostatecznej podstawy oceniającej są niemożliwe, musi on zdać się na zastany - a więc zawsze stronniczy - system znaczeńn ${ }^{28}$.

Również w odniesieniu do sztuki zauważono dość szybko, że ironiczny dystans do rzeczywistości i nastrój zabawy, bardzo trudno - jeśli w ogóle to możliwe - pogodzić z usiłowaniami mityzacji tejże rzeczywistości w światach przedstawionych; mityzacji mającej na celu podniesienie kondycji człowieka, z natury nieokreślonej, do rangi czegoś wzniosłego i tajemniczego. Jakoż sztuka postmodernistyczna nie mogła zapewnić tego, czego wprawdzie nie obiecywała, lecz czego oczekiwano po niej skrycie - formacji duchowej. W literaturze światowej bardzo ciekawego przykładu dostarcza w tej mierze, by nie sięgać

28 R. Legutko, Postmodernizm. Tekst dostępny na stronie: http://www.omp.org. $\mathrm{pl} /$ stareomp $/$ index9059. $\mathrm{php}$ ? module $=$ subjects $\&$ func $=$ viewpage $\&$ pageid $=314$ (dostęp: 17.08.2014 r.). 
daleko, niezwykle popularna również w Polsce Moskwa-Pietuszki Wieniedikta Jerofiejewa ${ }^{29}$.

Ponadto, wyobraźnię w roli demiurga nowego, lepszego świata dezawuuje notorycznie zdrowy rozsądek, który będąc ukształtowanym w cieniu oświeceniowej racjonalności i kultu nauk przyrodniczych jest obecnie czymś zarazem więcej i mniej niż potoczny zdrowy rozsądek - jest mianowicie wszystko obejmującym sceptycyzmem; nieliczenie się z nim to pięta Achillesowa wszystkich ponowoczesnych projektów, które w takiej czy innej formie próbują nawiązywać do dawnych esencjalistycznych kategorii ładu (wyobrażenie ,nowego, wspaniałego świata" demokracji liberalnej odwołuje się wszak w swoich warstwach ukrytych do utopii społecznych dawnego typu). Zachodzi tu niewątpliwie szereg okoliczności będących odbiciem Weberowskiego Odczarowania (Entzauberung der Welt), a bodaj najbardziej rujnujący jest ów proces dla myślenia w kategoriach „wyższych wymiarów”, wykraczania poza doczesność, przyziemność, trywialność etc. Dostaje się przy tym i postmodernistycznemu ersatzowi metafizyki - „nieskończoności”. Dla człowieka współczesnego, jak zauważa Rorty, „nieskończoność traci swój urok". Również w swojej odmianie postmodernistycznej: umowność tej kategorii sprawia, że człowiek nie osiąga zaspokojenia - w żadnym istotnym sensie tego pojęcia - potrzeby formacji (wszak chcemy być autentyczni, nie tylko ,skonstruowani”, choćby nawet najbardziej udanie i frapująco). Zdaniem amerykańskiego filozofa

stajemy się zdroworozsądkowymi finitystami - ludźmi przekonanymi, że po śmierci się gnije, że każde pokolenie, rozwiązując stare problemy, stwarza nowe, że potomni będą z niedowierzaniem i pogardą traktować wiele z tego, co zdziałaliśmy, i że postęp w stronę większej sprawiedliwości i wolności nie jest ani nieuchronny, ani niemożliwy. Zadowalamy się pojmowaniem siebie jako gatunku zwierzęcego, który usiłuje jakoś sobie radzić. Sekularyzacja wysokiej kultury zainspirowana przez takich myślicieli, jak Spinoza i Kant, wyrobiła w nas nawyk myślenia raczej horyzontalnego niż wertykalnego - służącego działaniu na rzecz choćby

Powieść ta, rozpatrywana na płaszczyźnie intertekstualnej, jest przebogatym kolażem cytatów i odniesień do rozległego świata kultury, które głównemu bohaterowi i zarazem narratorowi, Wieniczce Jerofiejewowi, mają dać namiastkę integralności duchowej. Ale jak zauważa literaturoznawca Andrzej Dudek: „Stan kultury w ujęciu Wieniczki Jerofiejewa to odzwierciedlenie dzisiejszego zagubienia człowieka, przytłoczonego chaosem szumów informacyjnych. W tych warunkach znajomość arcydzieł literatury i sztuki jest tylko pewną porcją nieuporządkowanej wiedzy, w żadnej mierze nie zapewniającej formacji duchowej." A. Dudek, Droga Krzyżowa Wieniczki Jerofiejewa albo Rosja wódka umyta. O powieści „Moskwa-Pietuszki”, [w:] L. Suchanek (red.), Emigracja i tamizdat. Szkice o wspótczesnej prozie rosyjskiej, Kraków 1993, s. 259. 
odrobinę lepszej przyszłości niż spoglądaniu wzwyż ku zewnętrznym ramom lub w dół w niezmierzone głębie. Filozofowie, którzy uważają, że wszystko to przebiega tak jak powinno, mogą czerpać smutną satysfakcję z postępującej stopniowo utraty własnego znaczenia ${ }^{30}$.

Niezależnie od tego, co zaprezentowano wcześniej, wydaje się, że wysiłki esencjalistów i konstruktywistów łączy pewien głębszy związek. Wyraża się on troską o podniesienie godności człowieka na wyższy poziom lub niekiedy - ocalenia resztek tej godności w obliczu zmian, jakie przyniosła ponowoczesność. W tym aspekcie mniemana obcość obu ruchów jest pozorna i nie skłania do pesymizmu tak wielkiego, jaki jest udziałem niektórych esencjalistów. Należy sądzić, że problem - w odniesieniu do wyodrębnionej tu kwestii - polega na czym innym. Na tym, o czym nie zdążyliśmy powiedzieć, a co należy uznać za bardzo doniosłe ze względu na przebieg dzisiejszej debaty nad człowiekiem. Otóż strony naszego konfliktu cechuje pewna asymetria w zakresie przestrzegania standardów etycznych. Konstruktywizmowi właściwa jest, nie w całości, rzecz jasna, i nie w każdych okolicznościach, niemniej zauważalnie, pewna nieuczciwość. Jak się to objawia? Otóż, po pierwsze, stawiając się w roli apostoła wolności, przypisuje on sobie zarazem właściwość jej wyłącznego reprezentanta. Choć, jak wiadomo, głosi się wyznawcą powszechnej równości, programowo kultywuje dystans wobec dyskursywnych zawłaszczeń etc. Po drugie, wykazuje myślenie konstruktywistyczne głęboką nietolerancję w stosunku do tych, których sytuuje w roli przeciwników ideowych (czytaj - wrogów wolności); nietolerancję, by tak rzec, najdalej idącą wykazuje wobec kościołów chrześcijańskich (w szczególności katolickiego). Przy czym jest rzeczą charakterystyczną, że wrogiem wolności może być tutaj w zasadzie każdy, kogo myślenie ujawnia powinowactwa z którymś z esencjalistycznych paradygmatów; przesądzają o tym czasem względy merytoryczne, a czasem po prostu polityczna koniunktura ${ }^{31}$. Dlatego

30 R. Rorty, Wielkość, głębia i skończoność, [w:] R. Rorty, Filozofia jako polityka kulturalna, przekł. B. Baran, Warszawa 2009, s. 144.

31 Podkreśliliśmy wcześniej doniosłość wyjścia dyskursu emancypacyjnego poza granice ukształtowanej przez myśl oświeceniową utopii. Jego polityzacja, oznaczająca m.in. zinstrumentowanie do roli narzędzia społecznej regulacji (bądź deregulacji) jest dzisiaj chyba najbardziej widocznym i odczuwalnym skutkiem owego przekroczenia utopii. Co się tyczy poglądu, że wspólnota jest instancją nadrzędną (a nawet jedyną) w dziedzinie regulacji moralnych, to trzeba odnotować, że nie jest on dziś ekscentryczny również po stronie „esencjalistów”: hołduje mu pewna liczba odmian myśli liberalnej, choć czyni to jednocześnie w oparciu o twarde (ahistoryczne) rozumienie „,natury ludzkiej” lub przynajmniej do takiego rozumienia się skłaniając. Jeśli nawet przyjąć, z dzisiejszego, anachronicznego stanowiska, że wspólnota zawsze była faktycznym źródłem 
granica między przyjaciółmi a wrogami wolności wytyczana bywa i przesuwana dość dowolnie. Niebezpieczeństwa te zaczęto dostrzegać już w XVIII wieku, a więc u samych źródeł procesu emancypacyjnego; jednym z pierwszych wnikliwych krytyków uroszczeń religii wolnościowej był biskup George Berkeley ${ }^{32}$.

Trzecim wreszcie przejawem nieuczciwości obozu konstruktywistycznego, który godzi się specjalnie wyróżnić ze względu na jego wagę, jest sam sposób prowadzenia sporu. Najczęściej polega on na postponowaniu stanowiska adwersarzy poprzez przypisywanie mu negatywnego kwalifikatora moralnego związanego z jakąś jego, mniemaną lub faktyczną, cechą społeczną (,władza”, ,przemoc symboliczna”, „dominacja”, „patriarchalizm”, „seksizm” etc.). W ten sposób zdarza się niejednokrotnie, że diagnoza danego stanu rzeczy sprowadza się do obsesyjnego wręcz tropienia w niej momentów dezawuujących (vide pojęcie „władzy” w filozofii Michaela Foucaulta).

Jak się mają wymienione uwagi do zagadnienia człowieczeństwa, o którego godność i status (jak zauważyliśmy), toczy się batalia w ramach generalnego antagonizmu dwóch wielkich ruchów myśli, o jakich mówimy? Przede wszystkim podkreślić trzeba, że bezustanne odzieranie podmiotowości człowieka z kolejnych jej esencjalnych umocowań (dziecko Boże, istota rozumna, uczestnik procesu dziejowego etc.) wystawia tę podmiotowość na niszczące, a już na pewno co najmniej niebezpieczne, działanie polityzacji. W ten sposób staje się godność ludzka zakładniczką dobrej woli tych, którzy kształtują wspólnotę. Respekt dla „czynnika X” (Fukuyama) przestaje być funkcją wielu współokreślających go dotychczas łącznie przesłanek: charakteru tradycji, argumentów filozoficznych, wrażliwości moralnej społeczeństwa etc. Dziś jego występowanie lub brak zależy funkcjonalnie od deliberatywnych mocy wspólnoty liberalnej (mówimy tu zatem o polityzacji nie w wąskim, technicznym sensie, ale najszerszym - wspólnotowym).

kreacji norm moralnych, nie unieważnia to wcale stanowiska przeciwnego - że kreacji tej dokonywała zgodnie z pewną, niezależną od niej, „,naturą rzeczy”.

W mniej znanym swoim dziele, niedawno po raz pierwszy wydanym w Polsce dialogu filozoficznym Alkifron. - Mikołaj Olszewski, autor wstępu do polskiego wydania, pisze: „Berkeley dostrzega, że kwestią podstawową dla wolnomyślicieli jest przekonanie postronnych, że rozum i wolność są po ich stronie.[...] określenie «wolnomyśliciel», odwołujące się do ideału nieskrępowanego niczym odkrywania prawdy, który drogi jest wszystkim, oraz kojarzące się z wolnością i rozumem, niekwestionowanymi wartościami, skłania do wstępnej przychylności do sekty, przypisuje z góry do lepszej strony barykady - zalicza do obrońców wolności i ludzi mądrych. Tymczasem faktycznie jest to uproszczenie”. M. Olszewski, Alkifron - pierwszy zdekonstruowany filozof oświeceniowy, [w:] G. Berkeley, Alkifron, przekł. M. Olszewski, Kęty 2008, s. 11. 
A jednak możliwa wydaje się sytuacja, w której konstruktywizm i esencjalizm (najogólniej pojęte) stają się siłami działającymi dla Nauka wspólnego dobra: realizacji idei człowieczeństwa z jej aspiracjami do wyższych przeznaczeń i z uwzględnieniem jej naturalnej wielostronności. Warunkiem byłaby demonopolizacja projektu wolnościowego (zawłaszczonego faktycznie przez konstruktywistów) i uczynienie go realną własnością wszystkich uczestników dyskursu. Realną, to znaczy w pierwszym rzędzie opartą na rzetelności i uczciwości. Przestrzeganie zaś tych ostatnich skłaniałoby do poszanowania różnorodności stanowisk antropologicznych, z których każde (dotyczyłoby to przynajmniej tych otwartych na uczestnictwo w polilogu), mogłoby jawić się jako wzbogacające ogólną perspektywę człowieczeństwa. Jak mądrze to ujął w swoim czasie Raymond Aron:

Stająca się ludzka rzeczywistość ma swoją strukturę, czyny tworzą pewne zespoły czynów, jednostki są związane z ustrojami, idee układają się w doktrynę. Nie należy przypisywać zachowaniu się czy myślom innych ludzi znaczenia, jakie my odczytujemy z wydarzeń. Ostatnie słowo nie jest nigdy wypowiedziane i nie trzeba sądzić przeciwników tak, jakby nasza sprawa była wyrazem ostatecznej prawdy ${ }^{33}$.

Gdy spróbujemy dostrzec w dzisiejszej konstruktywistyczno-esencjalistycznej psychomachii źródła zarówno zagrożeń, jak i nadziei, i gdy postaramy się zarazem obrać względem niej punkt widzenia możliwie najbardziej niezależny (choć na prawdziwie niezależny zdobyć się, jak wiadomo, nie sposób), trudno będzie nam zapewne oprzeć się wrażeniu, że w istocie ważniejszym od tego, kto „ma rację”, jest to, jak tę rację próbuje uwiarygodnić. W świecie nieusuwalnie, jak się wydaje, spluralizowanym fundamentalnego znaczenia nabiera intelektualna uczciwość i moralna powściągliwość w ocenie ideowego oponenta. Wszystko to aktualizuje, po raz kolejny w dziejach, lecz w nowym duchu, chrześcijańską wizję człowieka jako istoty, której tożsamość określają zarówno czynniki historycznie zmienne, jak i historycznej zmienności się wymykające. A to, czy ponowoczesność okaże się w ostatecznym rozrachunku epoką trwałej degradacji człowieka, czy też zaczynem nowego, pozytywnego, „przewartościowania”, zależeć będzie w znacznym stopniu od sumień ludzi tego przewartościowania dokonujących.

Słowa kluczowe: ponowoczesność, człowieczeństwo, esencjalizm, konstruktywizm, konflikt.

33 R. Aron, Opium intelektualistów, przekł. Cz. Miłosz, Warszawa 2000, s. 181. 